\title{
DINOFLAGELLATE CYSTS IN SURFACE SEDIMENTS AT VAN PHONG BAY, KHANH HOA PROVINCE, VIETNAM: DISTRIBUTION, ABUNDANCE AND POTENTIALLY HARMFUL ALGAL BLOOMS
}

\author{
Phan Tan Luom ${ }^{1,2, *}$, Doan Nhu Hai', Nguyen Ngoc Lam² \\ ${ }^{1}$ Graduate University of Science and Technology, VAST, Vietnam \\ ${ }^{2}$ Institute of Oceanography, VAST, Vietnam
}

Received 22 August 2020, accepted 24 February 2021

\begin{abstract}
Studies on dinoflagellate cysts provide important knowledge on the ecology of dinoflagellates and harmful algal blooms (HABs). In this study, distribution and abundance of dinoflagellate cysts in surface sediments from 17 stations at Van Phong Bay were analyzed. There were 55 different types of cysts representing 3 orders and 18 genera, and 8 unidentified cyst types recorded. Peridiniales was the most diverse order with 29 cyst types, including 20 Protoperidinium cyst types. There were 10 cyst types of 7 potential toxic dinoflagellate species and 4 of bloom forming species found, indicating a potential risk of harmful algal blooms in Van Phong Bay. Number of cyst types and density ranged from 12 to 31 types and from 115 to 3,760 per gram of dry weight sediment, respectively. Cysts of Leonella granifera were dominant at stations in the mouth of the Bay, while Scrippsiella trochoidea cysts dominated at all stations. Shannon diversity index $\left(\mathrm{H}^{\prime}\right)$ was low, varying from 1.19 to 2.72 . There were two distinct cyst assemblages identified with $40 \%$ Bray-Curtis similarity, assemblage I with 2 stations (VP09 and VP10), and assemblage II with the other stations.
\end{abstract}

Keywords: Dinoflagellate cyst, Protoperidinium cyst, potentially HABs, sediment, Van Phong Bay, Vietnam.

Citation: Phan Tan Luom, Doan Nhu Hai, Nguyen Ngoc Lam, 2021. Dinoflagellate cysts in surface sediments at Van Phong Bay, Khanh Hoa Province, Vietnam: distribution, abundance and potentially harmful algal blooms. Academia Journal of Biology, 43(1): 39-52. https://doi.org/10.15625/2615-9023/15404

*Corresponding author email: luom.dt@gmail.com

C2021 Vietnam Academy of Science and Technology (VAST) 


\section{INTRODUCTION}

Van Phong Bay (VPB) is located in the northern part of Khanh Hoa Province, surrounded by districts Van Ninh and Ninh Hoa. It has an area of ca. 150,000 hectares, with 80,000 hectares of surface water. The inner part of the bay has depths less than 20 $\mathrm{m}$, while it is slightly deeper $(20-30 \mathrm{~m})$ in the outer part, and the Co Co area is deeper than $34 \mathrm{~m}$. Cua Be channel is connected to the open sea. Surface sediment in Van Phong Bay is dominated by sand, silt and clay, in which silt and clay cover the largest area (Pham Ba Trung et al., 2014). Recently, VPB has been having substantial development in coastal aquaculture, tourism, coastal construction and urban planning by the local government. The negative aspect of this development is the adverse impact on the environment that directly and indirectly cause blooms of phytoplankton that can harm the marine ecosystem and human health (Doan-Nhu et al., 2017).

Dinoflagellates are a major component of the phytoplankton and play an important role in the marine ecosystem. Many marine dinoflagellates include species that cause red tides, shellfish poisoning and other harmful events (Matsuoka et al., 2003). More than 80 species of these are known to have resting cyst stage as a part of their sexual cycle (Matsuoka \& Fukuyo, 2000), often in response to harsh conditions (Mertens et al., 2012). Resting cysts can survive unfavorable environmental conditions and, therefore have an important role as a seeding source. Cysts sink to the seafloor in the same manner as fine particles (Dale, 1983) and have a mandatory resting period, after which they re-establish a motile population (Anderson, 1997; Pospelova et al., 2010). Linking these cysts to their respective motile stage is important for both biological and geological studies (Mertens et al., 2012). Cysts, therefore, significantly control the population dynamics of the planktonic stages of many dinoflagellates (Pitcher \& Joyce, 2009).

Moreover, knowledge of the distribution and abundance of cysts can be very useful in ecological and monitoring investigations (Qi et al., 1996). Dinoflagellates cysts in marine sediments have been studied in many areas such as Woods Hole (Wall \& Dale, 1968), Japan (Matsuoka, 1985, 1987), Australia (Bolch \& Hallegraeff, 1990), the North Sea (Nehring, 1994), and the Gulf of Gemlik (Balkis et al., 2016). In Southeast Asia, research on the distribution of dinoflagellates cysts has been conducted in the Gulf of Thailand and East Coast of Peninsular Malaysia by Lirdwitayaprasit (1999). Twenty different types of cysts belonging to Goniolacoid, Tuberculodinioid, and Peridinioid were found. However, cysts of harmful species were not observed. In Manila Bay, dominance of Pyrodinium cysts was reported over the other 23 dinoflagellates cyst types (Azanza et al., 2004). In the offshore waters of the Bien Dong, intensive investigation has been done on Sunda Shelf and shelf of centre Vietnam (Kawamura, 2002). From this research, 45 organic-wall dinoflagellate cysts were found in the Bien Dong (Kawamura, 2002) and 35 were found on Sunda shelf (Kawamura, 2004). In Vietnam, knowledge of the composition and distribution of dinoflagellate cysts is limited. The first screening of dinoflagellate cysts was carried out in Cam Ranh Bay, Central Vietnam by Doan Nhu Hai \& Nguyen Ngoc Lam (2002), where 25 cysts of different species were recorded and illustrated. Phan Tan Luom et al. (2017) described and illustrated in details 8 different types of cysts belonging to the genus Protoperidinium from seven stations in Phu Yen, Khanh Hoa and Ninh Thuan Provinces, South Central Vietnam.

The study of dinoflagellate cysts is important for understanding bloom mechanisms and possible oceanographic conditions associated with harmful algal blooms (HAB). In this paper, we presented the spatial distribution and abundance of dinoflagellate cysts in surface sediment of Van Phong Bay, Khanh Hoa Province, Vietnam.

\section{MATERIALS AND METHODS}

\section{Sampling}

Surface sediment samples were collected using a Petersen grab in June 2017 
from 17 stations in Van Phong Bay, Khanh Hoa (Figure 1 and Table 1). The samples were stored in the dark at $4{ }^{\circ} \mathrm{C}$ for later study.

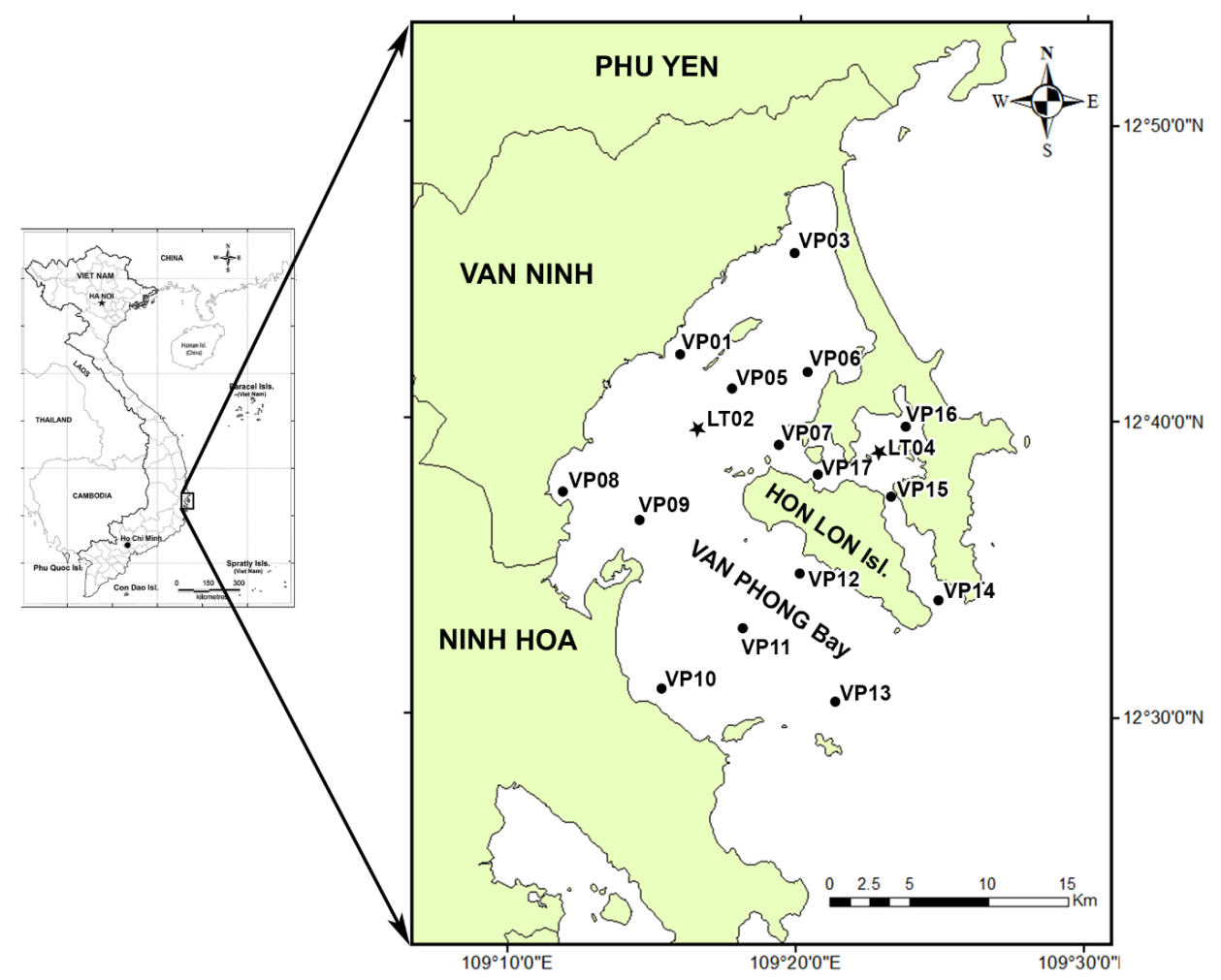

Figure 1. The map shows the 17 sampling stations in Van Phong Bay, Khanh Hoa

Table 1. Coordinates and water depths of sampling stations

\begin{tabular}{|c|c|r|c|}
\hline Station & Longitude (E) & Latitude (N) & Water depth (m) \\
\hline VP01 & 109.2680 & 12.7026 & 6.40 \\
\hline LT-02 & 109.2891 & 12.7257 & 7.00 \\
\hline VP03 & 109.3312 & 12.7584 & 7.00 \\
\hline LT-04 & 109.3266 & 12.7203 & 10.0 \\
\hline VP05 & 109.2969 & 12.6840 & 13.0 \\
\hline VP06 & 109.3396 & 12.6927 & 14.0 \\
\hline VP07 & 109.3231 & 12.6527 & 18.3 \\
\hline VP08 & 109.2010 & 12.6270 & 7.50 \\
\hline VP09 & 109.2449 & 12.6130 & 13.5 \\
\hline VP10 & 109.2570 & 12.5205 & 18.3 \\
\hline VP11 & 109.3027 & 12.5528 & 23.0 \\
\hline VP12 & 109.3357 & 12.5830 & 22.7 \\
\hline VP13 & 109.3545 & 12.5122 & 28.0 \\
\hline VP14 & 109.4135 & 12.5687 & 28.0 \\
\hline VP15 & 109.3878 & 12.6251 & 39.0 \\
\hline VP16 & 109.3950 & 12.6628 & 21.3 \\
\hline VP17 & 109.3454 & 12.6372 & 22.8 \\
\hline
\end{tabular}




\section{Analyses of samples}

Wet sediment samples were divided into three subsamples with equal weight. One subsample was oven-dried at $70{ }^{\circ} \mathrm{C}$ for 24 hours to determine dry weight, two others were sieved for qualitative and quantitative analysis. Sediment processing generally followed the methods of Bolch \& Hallegraeff (1990) and Matsuoka \& Fukuyo (2000); approximately 4-5 g wet sediment were mixed with $0.2 \mu \mathrm{m}$ filtered seawater and sonicated for 2 min using an Ultrasonic Processor (Name instrument, Nation) and then successively sieved through 125 and $20 \mu \mathrm{m}$ metallic sieves ( 2 to 3 times) to remove coarse and fine materials. The samples retained on the $20 \mu \mathrm{m}$ sieve were transferred into a plastic tube and suspended in $10 \mathrm{ml}$ distilled water.

One-milliliter aliquots from subsample were counted in Sedgwick-Rafter counting chamber and a Leica LDMB microscope (Germany) at a magnification of 100x. Cyst abundance was calculated as cysts per gram dry weight sediment (cysts $\mathrm{g}^{-1} \mathrm{DW}$ ). Data analyses were performed using MS Excel 2010 and the PRIMER v6 package, in which the Shannon-Wiener index, hierarchical cluster and multidimensional scaling (MDS) were computed. Dinoflagellate cysts were identified based on published descriptions of Wall and Dale (1968), Matsuoka (1987), Bolch \& Hallegraeff (1990), and Matsuoka \& Fukuyo (2000).

\section{RESULTS}

There were 55 different types of dinoflagellate cysts belonging to 3 orders and 18 genera, and 8 unidentified cyst types recorded (Appendix). Peridiniales was the most diverse order with 29 cyst types, including 20 Protoperidinium species. Orders Gonyaulacales and Gymnodiniales had 18 and 8 cyst types, respectively (Tab. 2 and Fig. 2). Among 55 cyst types identified, 24 heterotrophic cyst types, which mainly consisted of Protoperidinium (20 cyst types), Polykrikos sp., Diplopelta parva, Diplosalis cf. lebourae, and Zygabikodinium lenticulatum, accounted for $43.64 \%$ of total dinoflagellate cyst assemblages recorded at most sampling sites. Meanwhile, there were 31 autotrophic cyst types (56.36\%).

Table 2. Structure of the composition of dinoflagellate cysts in the surface sediment of Van Phong Bay

\begin{tabular}{|l|c|c|c|}
\hline \multicolumn{1}{|c|}{ Order } & Genus & $\begin{array}{c}\text { Cyst } \\
\text { types }\end{array}$ & $\begin{array}{c}\text { Percentage } \\
(\%)\end{array}$ \\
\hline Gonyaulacales & 4 & 18 & 28.57 \\
\hline Gymnodiniales & 5 & 8 & 12.70 \\
\hline Peridiniales & 9 & 29 & 46.03 \\
\hline Unknown & 0 & 8 & 12.70 \\
\hline Total & 18 & 63 & 100.00 \\
\hline
\end{tabular}

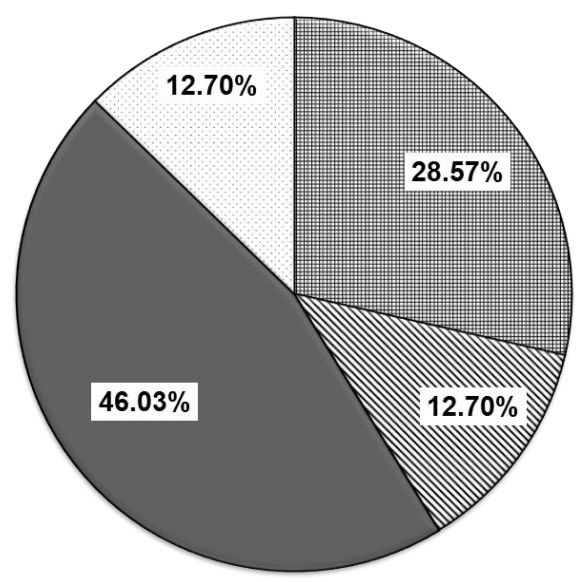

\section{Gonyaulacales $\mathbb{Q}$ Gymnodiniales \\ $\square$ Peridiniales $\square$ Unknown}

Figure 2. Percentage of different dinoflagellate cyst groups in the surface sediment of Van Phong Bay

The highest cyst abundance (3759 cysts $\mathrm{g}^{-1}$ DW) was recorded at station VP14 and the lowest (155 cysts $\left.\mathrm{g}^{-1} \mathrm{DW}\right)$ at station VP10 (Appendix and Fig. 3b). The number of cyst types were markedly higher (40-50 cyst types) at some innermost stations of the Bay (VP-01, VP-03, and VP-05), whereas the numbers were quite low (12-31 cyst types) at stations (VP-13 and VP-14) in the mouth of the Bay (Fig. 3a). Three cyst types, being Leonella granifera, Scrippsiella trochoidea, and unidentified brown dark round cysts, were commonly found at most stations (Fig. 4). 


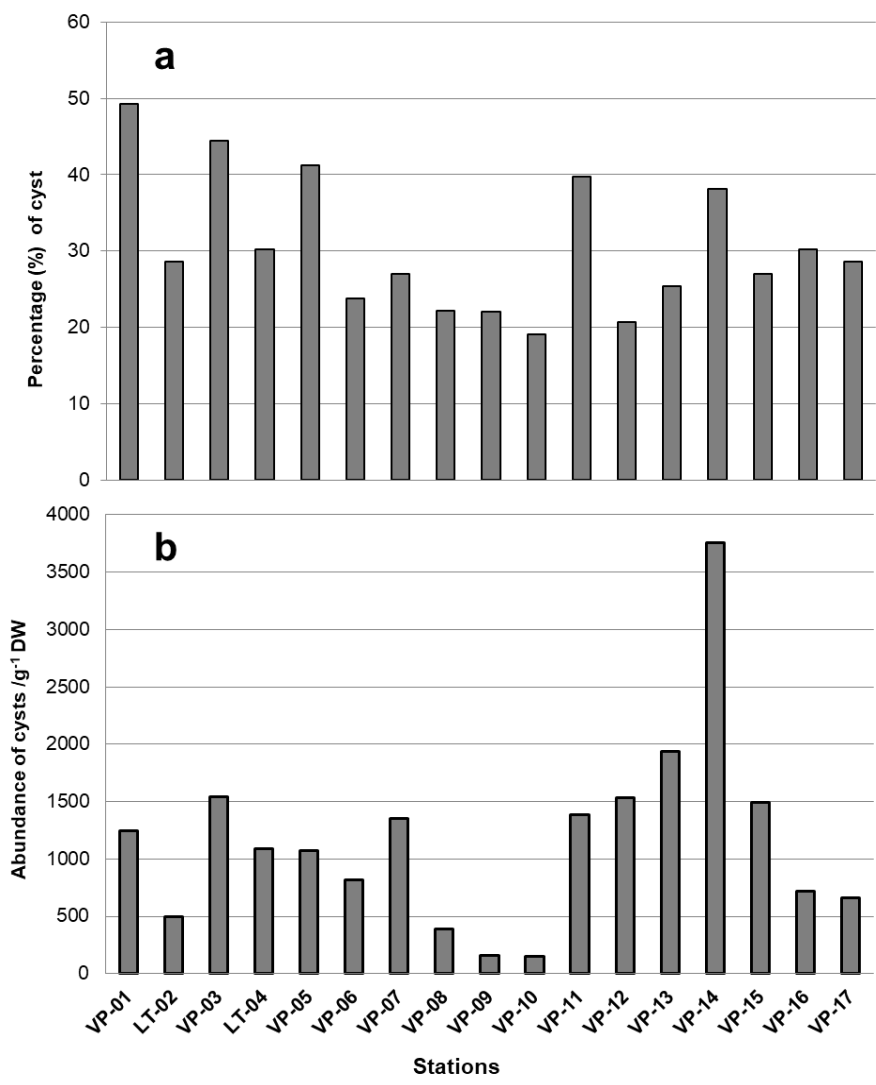

Figure $3 a-b$. Percentage of cysts composition (a) and abundance of cysts $\left(\mathrm{g}^{-1} \mathrm{DW}\right)$,

(b) at each station in Van Phong Bay

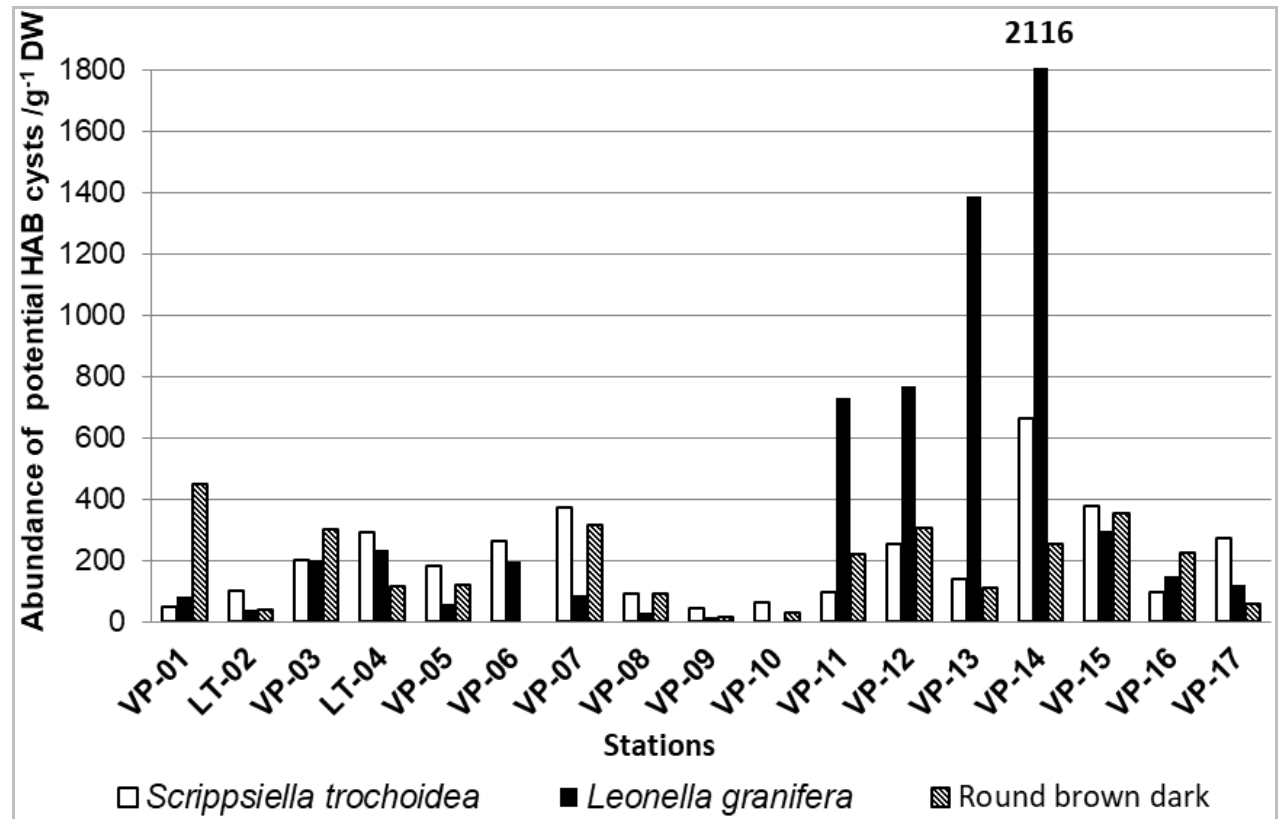

Figure 4. The abundance of potential bloom forming cysts at each station in Van Phong Bay 

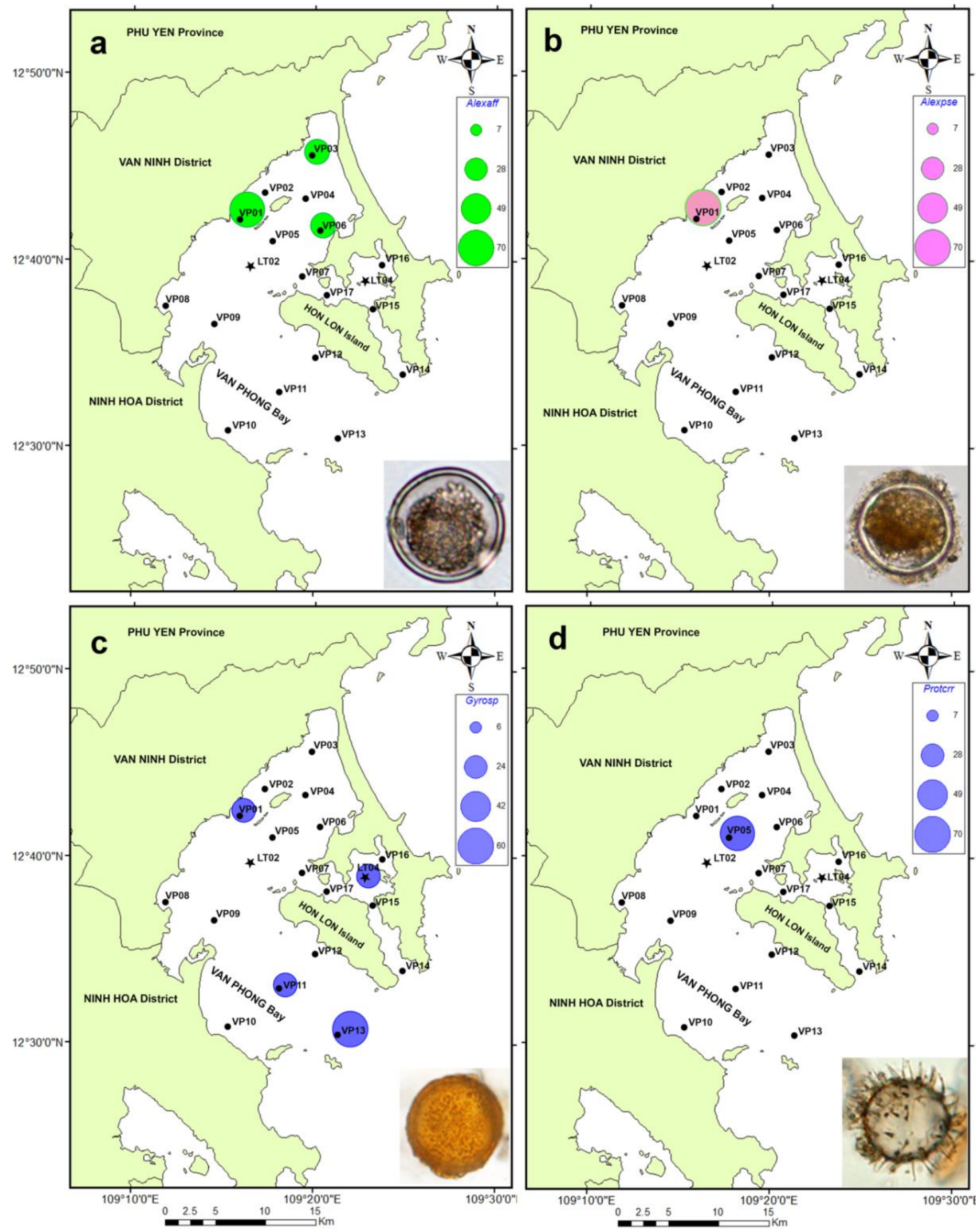

Figure $5 a-5 d$. Distribution of potential HAB cysts recorded. (a) Alexandrium affine,

(b) A. pseudogonyaulax, (c) Gymnodinium sp., (d) Protoceratium reticulatum

Among 55 identified cyst types, 10 cyst recorded in the study area, indicating a types of 7 potential $\mathrm{HAB}$ species were potential risk for outbreaks of harmful events 
associated with these in the future. Lingulodinium polyedrum, Protoceratium reticulatum, and Gonyaulax spinifera complex, are known to produce yessotoxin (YTXs). In addition, four potential forms recognized as paralytic shellfish poisoning (PSP) producer, comprising Alexandrium affine, A. catenella/tamarense, A. pseudogonyaulax, and Gymnodinium catenatum, were recorded at low numbers in the most stations (Fig. 5a-5d). Common bloom-forming species including Scrippsiella trochoidea, Leonella granifera, and brown dark round cysts were observed at high concentration (Fig. 4).

A cluster analysis of all stations revealed two different assemblages with $40 \%$ BrayCurtis similarity within the Bay (Fig. 6a-b). Assemblage I included 2 stations (VP09 and VP10) and was separated from the main group (assemblage II) due to its low abundance and species richness. Cysts of Scrippsiella trochoidea dominated at these two stations. Shannon diversity index $\left(\mathrm{H}^{\prime}\right)$ was low in the study area, varying from 1.19 to 2.72 .
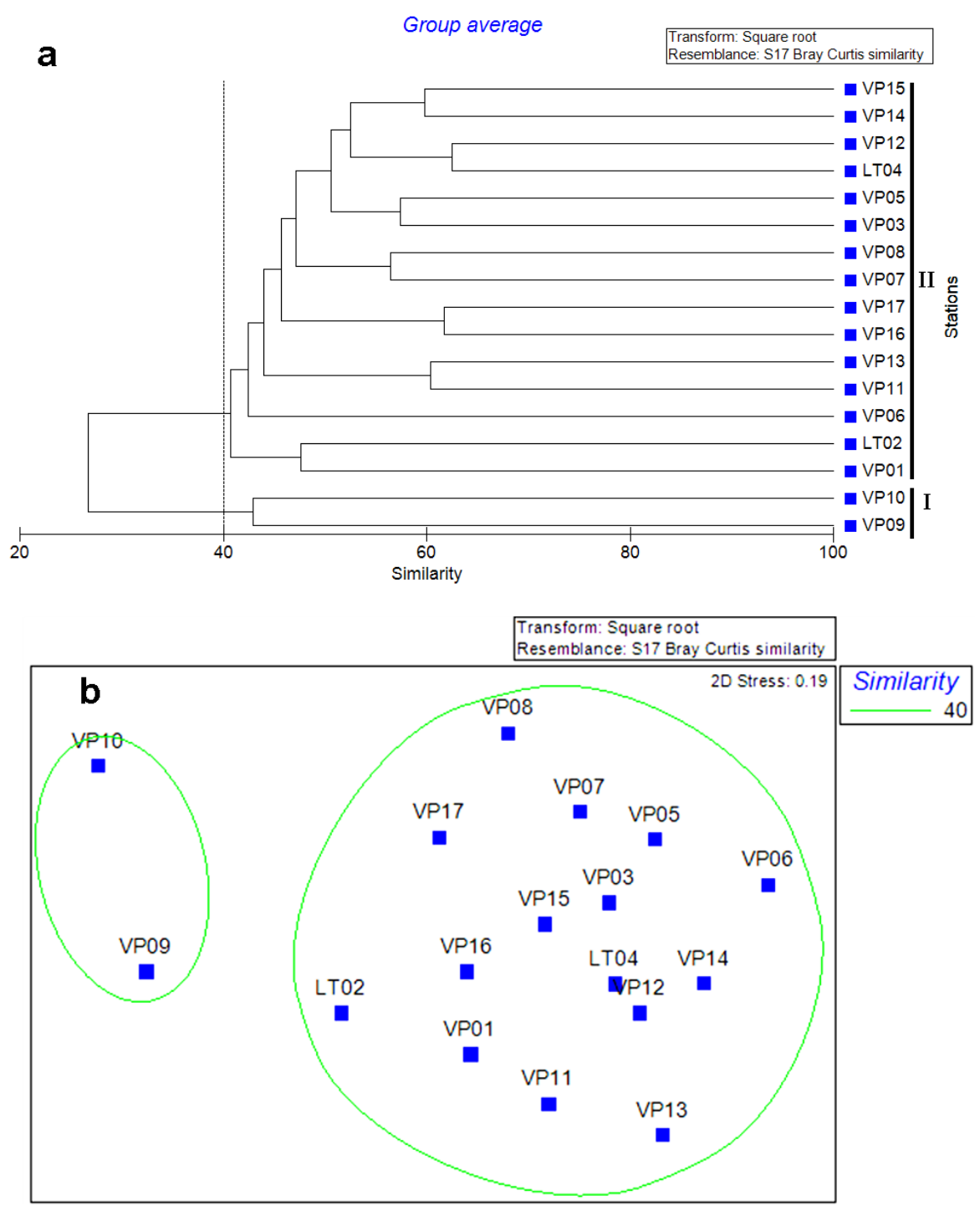

Figure 6a-6b. Similarity analysis for dinoflagellate cysts from 17 stations in Van Phong Bay.

(a) hierarchical cluster, (b) MDS 


\section{DISCUSION}

This is the first study providing knowledge of the distribution and abundance of dinoflagellate cysts in Van Phong Bay, Vietnam. Sixty-three different cyst morphotypes were found in the studied area. Among them, there were 31 types of autotrophic and 24 types of heterotrophic species. The number of cyst types found in Van Phong Bay was higher than in Cam Ranh Bay: 25 cyst types (Doan Nhu Hai \& Nguyen Ngoc Lam, 2002) and in the Gulf of Thailand and East Coast of Peninsular Malaysia: 20 cyst types (Lirdwitayaprasit, 1999). However, cysts of harmful species have not been observed in either of those studies.

Among the previous studies on dinoflagellate cysts on coastal waters, Van Phong Bay is the most diverse on cyst types (63) compared to the Gulf of Thailand: 18-30 (Lirdwitayaprasit, 1998; Srivilai et al., 2012), Malaysian coast: 11-25 (Furio et al., 2006), coastal waters of Indonesia: 5-35 (Matsuoka et al., 1999; Mizushima, 2007), and the Philippines; 23 (Azanza et al., 2004).

Cysts of Protoperidinium genus were the most diverse group with 20 cyst types recorded. The cysts of this genus were common and widespread, and they have also been found in other regions such as Woods Hole (Wall \& Dale, 1968), Japan (Matsuoka, 1985, 1987; Matsuoka et al., 2003), Australia (Bolch \& Hallegraeff, 1990), the Baltic Sea (Nehring, 1994), Gulf of Gemlik (Balkis et al., 2016), and China (Wang et al., 2003).

Leonella granifera cysts were found to be dominant at the mouth of Van Phong Bay. Only few species within this group were well studied, revealing their complex life cycle and distribution. An alternative life-cycle with the production of haploid vegetative calcareous cells as the dominant life-cycle stage was reported for the oceanic calcareous dinoflagellate such as and Leonella granifera (Meier et al., 2007) and Thoracosphaera heimii (Tangen et al., 1982). Van Phong Bay is open to a narrow shelf sea with just some 24 nautical miles to the shelf slope which explained the more abundance of $L$. granifera cysts at the mouth of the Bay. In this study we also found other calcareous cyst, Calciodinellum sp., with low numbers at few stations in the Bay. It was reported that a species of this genus, Calciodinellum levantinum, is a neritic species, forming calcareous cysts during the diploid stage (Meier et al., 2007).

In this study area, the cysts of some potentially toxic species, such as Gymnodinium catenatum cyst (PSP), were observed only at one station with low abundance. Gymnodinium catenatum is also a common bloom-forming species documented (Doblin et al., 1999; Band-Schmidt et al., 2010; Li et al., 2019), its bloom was reported in southern Tasmania (Anderson \& Morel, 1979; Hallegraeff, 1995).

The cyst of Diplopsalis sp., Leonella granifera, Scrippsiella trochoidea, and brown dark round cysts were observed in most samples. Although Scrippsiella trochoidea is not a toxin-producing species, it is also harmful to the marine ecosystem and mariculture due to high oxygen consumption during the bloom. Scrippsiella trochoidea bloom was recorded in Daya Bay, China (Wang et al., 2003), the number of this species blooms has increased 15 times since 1998 in this bay (Li et al., 2019).

Although cyst abundance of potentially toxic dinoflagellate species was not high, toxin-production was an important issue that harmed the marine aquaculture industry. In particular in mariculture area, besides monitoring vegetative cells in upper water body, it was essential to include investigation on dinoflagellate cysts in the sediment. In addition, high density of potentially HABs cysts could be considered a potential 'seedbed' for production of motile cells that can initiate subsequent blooms. These data also suggested that additional cyst surveys should be conducted in Vietnamese waters and that the potential for blooms of toxic species might be widespread. Further taxonomic and biogeographic studies are needed to better understand the ecological 
dynamics of oceanic plankton in the Vietnamese waters.

Acknowlegements: Doan Nhu Hai would like to thank the supporting programme for Senior Researchers via project NCCC17.03/20-20.

\section{REFERENCES}

Anderson D. M., 1997. Diversity of harmful algal blooms in coastal waters. Limnol. Oceanogr., 42: 1009-1022.

Anderson D. M., Morell F. M., 1979. The seeding of two red tide blooms by germination of benthic Gonyaulax tamarensis hypocyst. Estuar. Coast. Mar. Sci., 8: 279-293.

Azanza R. V., Siringan F. P., San DiegoMcglone M. L., Yñiguez A. T., Macalalad N. H., Zamora P. B., Agustin M. B., Matsuoka K., 2004. Horizontal dinoflagellate cyst distribution, sediment characteristics and benthic flux in Manila Bay, Philippines. Phycological Research, 52: 376-386.

Balkis N., Balci M., Giannakourou A., Venetsanopoulou A., Mudie P., 2016. Dinoflagellate resting cysts in recent marine sediments from the Gulf of Gemlik (Marmara Sea, Turkey) and seasonal harmful algal blooms. Phycologia, 55(2): 187-209.

Band-Schmidt C. J., Bustillos-Guzmán J. J., López-Cortés D. J., Gárate-Lizárraga I., Núñez-Vázquez E. J., HernándezSandoval F. E., 2010. Ecological and Physiological Studies of Gymnodinium catenatum in the Mexican Pacific: A Review. Mar. Drugs, 8: 1935-1961.

Bolch C. J. S., G. M. Hallegraeff, 1990. Dinoflagellate cysts in recent marine sediments from Tasminia, Australia. Botanica Marina, 33(2): 173-192.

Dale B., 1983. Dinoflagellate resting cysts: benthic plankton. In: G.A. Fryxell (Ed.) Survival strategies of the algae. Cambridge University Press pp. 69-136.

Doan Nhu Hai and Nguyen Ngoc Lam, 2002. Studies of HABs in Vietnamese waters:
Screening of Dinoflagellate cyst in sediments for historical blooms in Cam Ranh Bay, Central Vietnam. Proceeding IAEA/RCA Regional Technical Workshop on Radiometric Dating/Cysts Analysis Techniques and Receptor Binding assay for Harmful Algal Blooms Management (C1-RAS/8/076-9009-01). Cheevaporn, V. and Elvira, Z. Sombrito (eds). Burapha University's workshops, Thailand, pp. 137-144.

Doblin M. A., Blackburn S. I., Hallegraeff G. M., 1999. Comparative study of selenium requirements of three phytoplankton species: Gymnodinium catenatum, Alexandrium minutum (Dinophyta) and Chaetoceros cf. tenuissimus (Bacillariophyta). J. Plankton Res., 21(6): 1153-1169.

Furio E. F., Matsuoka K., Mizushima K., Baula I., Chan K. W., Puyong A., Srivilai D., Sidharta B. R., Fukuyo Y., 2006. Assemblage and geographical distribution of dinoflagellate cysts in surface sediments of coastal waters of Sabah, Malaysia. Coast. Mar. Sci., 30(1): 62-73.

Hai Doan-Nhu, Lam Nguyen-Ngoc, Son BuiMinh, 2017. Unusual fish killing blooms of Tripos furca in Van Phong Bay, South Vietnam. Harmful Algae News, An IOC Newsletter on Toxic Algae and Algal Blooms, 57: 1-3.

Hallegraeff G. M., 1995. Harmful algal blooms: a global review. In: Hallegraeff G. M., Anderson D. M., Cembella A.D. (Eds.). Manual on Harmful Marine Microalgae. IOC Manuals and Guides No. 33. UNESCO, Paris pp. 1-22.

Kawamura H., 2002. Marine palynological records in the southern South China Sea over the last $44 \mathrm{kyr}$ (Doctoral dissertation, Christian-Albrechts Universität Kiel).

Kawamura H., 2004. Dinoflagellate cyst distribution along a shelf to slope transect of an oligotrophic tropical sea (Sunda Shelf, South China Sea). Phycological Research, 52(4): 355-375. 
Li Y., Tang Ya-Nan, Shen Ping-Ping, Li G., Tan Ye-Hui, 2019. Distribution of harmful dinoflagellate cysts in the surface sediments of Daya Bay of the South China Sea and their relationship to environmental factors. International Biodeterioration \& Biodegradation, 139: 44-53.

Lirdwitayaprasit T., 1998. Distribution of dinoflagellate cysts in the surface sediment of the South China Sea, Area II: Sabah, Sarawak and Brunei Darussalam waters. In Proceedings of the second technical seminar on marine fishery resources survey in the South China Sea. Training Department, SEAFDEC, pp. 310-322.

Lirdwitayaprasit T., 1999. Distribution of dinoflagellate cysts in the surface sediment of the South China Sea, Area I: Gulf of Thailand and East Coast of Peninsular Malaysia. In Proceedings of the first technical seminar on marine fishery resources survey in the South China Sea. Training Department, SEAFDEC, pp. 294-309.

Phan Tan Luom, Nguyen Ngoc Lam, Doan Nhu Hai, 2017. Cysts of the genus Protoperidinium species in sediments from coastal waters of Phu Yen, Khanh Hoa and Ninh Thuan provinces, south central Vietnam. Tap chi Sinh hoc, 39(1): 32-39. https://doi.org/10.15625/08667160/v39n1.8403 (In Vietnamese with English summary).

Matsuoka K., 1985. Organic-walled dinoflagellate cysts from surface sediments of Nagasaki Bay and Senzaki Bay, West Japan. Faculty of Liberal Arts, Nagasaki University. Nat. Sci. Bull., 25: 1-17.

Matsuoka K., 1987. Organic-walled dinoflagellate cysts from surface sediments of Akkeshi Bay and Lake Saroma, North Japan. Bull. Fac. Liberal Arts Nagasaki Univ. Nat. Sci., 28: 35-123.

Matsuoka K., Fukuyo Y., 2000. Technical Guide for Modern Dinoflagellate Cyst
Study. WESTPAC-

HAB/WESTPAC/IOC, Japan Society for the Promotion of Science, pp. 29.

Matsuoka K., Fukuyo Y., Praseno D. P., Adnan Q., Kodama M., 1999. Dinoflagellate cysts in surface sediments of Jakarta Bay, off Ujung Pandang and Larantuka of Flores Island, Indonesia with special reference of Pyrodinium bahamense. Bull. Fac. Fish., Nagasaki Univ., 80: 49-54.

Matsuoka K., Joyce L.B., Kotani Y., Matsuyama Y., 2003. Modern dinoflagellate cysts in hypertrophic coastal waters of Tokyo Bay, Japan. $J$. Plankton Res., 25: 1461-1470.

Meier K. J., Young. S. J. R., Kirsch, M., Burkhardt. S. F., 2007. Evolution of different life-cycle strategies in oceanic calcareous dinoflagellates. European Journal of Phycology, 42(1): 81-89.

Mertens K. N., Yamaguchi A., Kawami H., Ribeiro S., Leander B.S., Price A. M., Pospelova V., Ellegaard M., Matsuoka K., 2012. Archaeperidinium saanichi sp. nov.: a new species based on morphological variation of cyst and theca within the Archaeperidinium minutum Jörgensen 1912 species complex. Mar. Micropaleontol., 96-97: 48-62.

Mizushima K., 2007. Spatial-temporal distribution of dinoflagellate cysts in Southeast Asia with special reference to Pyrodinium bahamense var. compressum. $\mathrm{PhD}$ Dissertation to Nagasaki University.

Nehring S., 1994. Spatial distribution of dinoflagellate resting cysts in recent sediments of Kiel Bight, Germany (Baltic Sea). Ophelia, 39 (2): 137-158.

Pitcher G. C., Joyce L. B., 2009. Dinoflagellate cyst production on the southern Namaqua shelf of the Benguela upwelling system. J. Plankton Res., 31: 865-875.

Pospelova V., Esenkulova S., Johannessen S. C., O'Brien M. C., Macdonald R. W., 2010. Organic-walled dinoflagellate cyst 
production, composition and flux from 1996 to 1998 in the central Strait of Georgia (BC, Canada): A sediment trap study. Marine Micropaleontology, 75(14): 17-37.

Qi Y. Z., Hong Y., Zheng L., Kulis D. M., Anderson D. M., 1996. Dinoflagellate cysts from recent marine sediments of the South and East China Seas. Asian Mar. Biol., 13: 87-103.

Srivilai D., Lirdwitayaprasit T., Fukuyo Y., 2012. Distribution of dinoflagellate cysts in the surface sediment of the coastal areas in Chonburi Province, Thailand. Coastal Marine Science, 35(1): 11-19.

Tangen K., Brand L. E., Blackwelder P. L., Guillard R. R. L., 1982. Thoracosphaera heimii (Lohmann) Kamptner is a dinophyte: observations on its morphology and life cycle. Marine Micropaleontology, 7: 193-212.

Pham Ba Trung, Nguyen Dinh Dan, Tran Van Binh, Trinh Minh Cuong, 2014. Topographical and sedimentological characteristics of Van Phong Bay, Khanh Hoa Province. Collection of Marine Research Works, 40: 44-52 (In Vietnamese with English summary).

Wall D., Dale B., 1968. Modern dinoflagellate cysts and evolution of the Peridiniales. Micropaleontology, 14: 265-304.

Wang Z. H., Matsuoka K., Qi, Y. Z., Gu X. L., 2003. Vertical distribution of dinoflagellate cysts in surface sediments from Shenzhen Bay of the South China Sea. Acta Ecologica Sinica, 23: 2073-81 (In Chinese with English summary). 
Phan Tan Luom et al.

\section{Appendix}

\begin{tabular}{|c|c|c|c|c|c|c|c|c|c|c|c|c|c|c|c|c|c|c|}
\hline \multirow[b]{2}{*}{ Ord. } & \multirow{2}{*}{ Cyst types } & \multicolumn{17}{|c|}{ Stations } \\
\hline & & VP01 & LT02 & VP03 & LT04 & VP05 & VP06 & VP07 & VP08 & VP09 & VP10 & VP11 & VP12 & VP13 & VP14 & VP15 & VP16 & VP17 \\
\hline \multicolumn{2}{|c|}{ Order Gonyaulacales } & 8 & 2 & 6 & 6 & 9 & 4 & 5 & 1 & 3 & 3 & 6 & 2 & 2 & 6 & 2 & 6 & 6 \\
\hline 1 & Alexandrium affine & + & & + & & + & + & & & & & & & & & & & \\
\hline 2 & Alexandrium catenella/tamarense & & & & & & & & & + & & & & & & & & \\
\hline 3 & Alexandrium pseudogonyaulax & + & & + & & + & + & + & & & & + & & & & & & + \\
\hline 4 & Alexandrium sp. & + & & & & + & & & & + & & & & & & & & + \\
\hline 5 & Gonyaulax scriipsae & + & & & + & + & + & & & & + & + & & & + & & + & + \\
\hline 6 & Gonyaulax sp.1 & & & & & & & & & & & + & & & + & + & + & + \\
\hline 7 & Gonyaulax sp.2 & + & & & & & & & & & & & & & & & + & \\
\hline 8 & Gonyaulax sp.3 & + & & + & + & + & & & & & & + & & & & & & + \\
\hline 9 & Gonyaulax sp.4 & & & & & & & + & & & + & & & & & & & \\
\hline 10 & Gonyaulax sp.5 & & & + & + & & + & + & & & & + & + & + & + & & + & \\
\hline 11 & Gonyaulax sp.6 & & & + & & + & & & & & & & & & + & + & & \\
\hline 12 & Gonyaulax spinifera & & & & + & + & & & & & + & + & & & & & & \\
\hline 13 & Gonyaulax spinifera & & & & & + & & & & & & & & & + & & + & \\
\hline 14 & Gonyaulax spinifera & & & & + & & & & & + & & & & & & & & \\
\hline 15 & Gonyaulax spinifera & + & + & + & & & & + & + & & & & + & & + & & & \\
\hline 16 & Lingulodium polyedrum & + & & & + & & & + & & & & & & + & & & + & + \\
\hline 17 & Protoceratium reticulatum & & & & & + & & & & & & & & & & & & \\
\hline 18 & Protoceratium sp. & & + & & & & & & & & & & & & & & & \\
\hline \multicolumn{2}{|c|}{ Percentages of Gonyaulacoid } & 12.70 & 3.17 & 9.52 & 9.52 & 14.29 & 6.35 & 7.94 & 1.59 & 4.76 & 4.76 & 9.52 & 3.17 & 3.17 & 9.52 & 3.17 & 9.52 & 9.52 \\
\hline \multicolumn{2}{|c|}{ Order Gymnodiniales } & 3 & 2 & 4 & 2 & 2 & 1 & 1 & 0 & 0 & 1 & 4 & 1 & 2 & 1 & 0 & 3 & 1 \\
\hline 19 & Cochlodinium sp.1 & + & & & & & & & & & & + & & + & & & & \\
\hline 20 & Cochlodinium sp.2 & & + & + & + & + & & & & & & & + & & & & & \\
\hline 21 & Gyrodinium catenatum & & & & & & & & & & & & & & & & + & \\
\hline 22 & Gyrodinium sp. & + & & + & + & & & & & & & + & & + & & & & \\
\hline 23 & Pheopolykrikos hartmannii & & & + & & + & & & & & & + & & & + & & + & + \\
\hline 24 & Pheopolykrikos sp. & & & & & & & & & & & + & & & & & & \\
\hline 25 & Polykrikos sp. & + & + & + & & & + & + & & & & & & & & & + & \\
\hline 26 & Pyrophacus steinii & & & & & & & & & & + & & & & & & & \\
\hline \multicolumn{2}{|c|}{ Percentages of Gymnodiniales } & 4.76 & 3.17 & 6.35 & 3.17 & 3.17 & 1.59 & 1.59 & 0.00 & 0.00 & 1.59 & 6.35 & 1.59 & 3.17 & 1.59 & 0.00 & 4.76 & 1.59 \\
\hline \multicolumn{2}{|c|}{ Order Peridiniales } & 16 & 10 & 14 & 9 & 13 & 8 & 10 & 10 & 9 & 5 & 11 & 7 & 10 & 13 & 11 & 9 & 9 \\
\hline 27 & Calciodinellum sp. & + & + & & & + & & + & & + & & + & & + & + & & & \\
\hline 28 & Diplopelta parva & + & & + & & + & + & + & + & & & & & & + & + & & \\
\hline 29 & Diplosalis cf. lebourae & + & + & & + & + & & & & + & & + & & & & + & & + \\
\hline
\end{tabular}


Dinoflagellate cysts in surface sediments

\begin{tabular}{|c|c|c|c|c|c|c|c|c|c|c|c|c|c|c|c|c|c|c|}
\hline 30 & Leonella granifera & + & + & + & + & + & + & + & + & + & & + & + & + & + & + & + & + \\
\hline 31 & Oblea acanthocysta & & & & & & & + & + & & & & & & & & + & \\
\hline 32 & Preperidinium cf. meunieri & + & & + & & & & & & & & & & & & & & \\
\hline 33 & Preperidinium $\mathrm{sp}$. & & & + & & & & & & & & & & & & & & \\
\hline 34 & Protoperidinium avellana & & & & & & & + & & & & & & + & + & & + & + \\
\hline 35 & P. conicoides & & + & & + & & & & & & & & & + & + & & & \\
\hline 36 & P.conicum & & & + & & & & & + & & & & + & & & & & \\
\hline 37 & P. denticulatum & + & & + & 3 & + & + & + & + & & + & + & + & + & + & + & & + \\
\hline 38 & Protoperidinium sp.1 & & & + & & & + & & + & & + & & & & + & + & & \\
\hline 39 & Protoperidinium sp. 2 & + & + & + & + & + & & & & + & + & + & & & + & + & + & \\
\hline 40 & Protoperidinium sp. 3 & + & + & & & & & & & & & & & & & + & & \\
\hline 41 & Protoperidinium sp. 4 & + & + & + & + & + & & + & + & + & & & + & & + & & + & + \\
\hline 42 & Protoperidinium sp.5 & & & & & & & & & + & & & & & & & & \\
\hline 43 & Protoperidinium sp.6 & + & + & + & + & + & + & & & + & & + & + & & + & & & + \\
\hline 44 & Protoperidinium sp.7 & + & & & & & & & & & & & & + & & + & + & \\
\hline 45 & Protoperidinium sp. 8 & & & & & & & & & & & & & & & & + & \\
\hline 46 & Protoperidinium sp.9 & & & & + & + & & & & & & + & & & & & & \\
\hline 47 & Protoperidinium sp.10 & & & + & & & & & & & & & & & & & & \\
\hline 48 & Protoperidinium sp.11 & + & & & & + & + & & + & & & & & & + & & & \\
\hline 49 & Protoperidinium sp.12 & + & & & & & & + & & & & + & & + & & & & \\
\hline 50 & Protoperidinium sp.13 & + & & + & & + & & + & + & & & & & + & + & + & & + \\
\hline 51 & P. stellatum & & & & & & & & & & & & & & & & & \\
\hline 52 & P. subinerma & & & & & & & & & & & + & & & & & & \\
\hline 53 & P. thulensense & & & & & & & & & & & & & + & & & & \\
\hline 54 & Scrippsiella trochoidea & + & + & + & + & + & + & + & + & + & + & + & + & + & + & + & + & + \\
\hline 55 & Zygabikodinium lenticulatum & + & + & + & & + & + & & & + & + & + & + & & & + & + & + \\
\hline \multicolumn{2}{|c|}{ Percentages of Peridiniales } & 25.40 & 15.87 & 22.22 & 14.29 & 20.63 & 12.70 & 15.87 & 15.87 & 14.29 & 7.94 & 17.46 & 11.11 & 15.87 & 20.63 & 17.46 & 14.29 & 14.29 \\
\hline \multicolumn{2}{|c|}{ Unidentified } & 4 & 4 & 4 & 2 & 2 & 2 & 1 & 3 & 2 & 3 & 4 & 3 & 2 & 4 & 4 & 1 & 2 \\
\hline 56 & Unidentified-1 & & & + & & & + & & & & & & & & + & & & \\
\hline 57 & Unidentified-2 & & & + & & & & & & & & & & + & & & & \\
\hline 58 & Unidentified-3 & + & + & + & & & & & & & & & & & + & & & \\
\hline 59 & Unidentified-4 & + & & & & & & & & + & & + & + & & + & + & & \\
\hline 60 & Unidentified-5 & & & & & & & & & & & + & + & & & & & \\
\hline 61 & Unidentified-6 & & + & & & + & & & + & & + & + & & & & + & & + \\
\hline 62 & Unidentified-7 & + & + & & + & & & & + & & + & & & & & + & & \\
\hline 63 & Round brown dark & + & + & + & + & + & + & + & + & + & + & + & + & + & + & + & + & + \\
\hline \multicolumn{2}{|c|}{ Percentages of unidentified } & 6.35 & 6.35 & 6.35 & 3.17 & 3.17 & 3.17 & 1.59 & 4.76 & 3.17 & 4.76 & 6.35 & 4.76 & 3.17 & 6.35 & 6.35 & 1.59 & 3.17 \\
\hline
\end{tabular}


Phan Tan Luom et al.

\begin{tabular}{|l|c|c|c|c|c|c|c|c|c|c|c|c|c|c|c|c|c|}
\hline Number of cysts/stations & 31 & 18 & 28 & 19 & 26 & 15 & 17 & 14 & 14 & 12 & 25 & 13 & 16 & 24 & 17 & 19 & 18 \\
\hline Percentages of cysts/stations & 49.21 & 28.57 & 44.44 & 30.16 & 41.27 & 23.81 & 26.98 & 22.22 & 22.22 & 19.05 & 39.68 & 20.63 & 25.40 & 38.10 & 26.98 & 30.16 & 28.57 \\
\hline Abundance cysts/g $\mathrm{g}^{-1}$ DW & 1249.58 & 497.96 & 1545.08 & 1086.57 & 1069.94 & 817.96 & 1351.51 & 391.70 & 159.26 & 155.18 & 1388.69 & 1533.35 & 1938.52 & 3758.69 & 1491.00 & 719.75 & 661.89 \\
\hline Number of cyst Autotrophyic & 11 & 5 & 9 & 7 & 10 & 5 & 6 & 4 & 4 & 1 & 9 & 4 & 6 & 9 & 4 & 6 & 6 \\
\hline Number of cyst Heterotrophyic & 13 & 9 & 11 & 7 & 10 & 8 & 7 & 9 & 7 & 8 & 12 & 8 & 10 & 10 & 11 & 8 & 8 \\
\hline Abundance of cyst Autotrophyic & 416.5 & 219.1 & 738.9 & 704.8 & 519.7 & 556.2 & 603.9 & 156.7 & 86.9 & 62.1 & $1,023.2$ & $1,073.3$ & $1,661.6$ & $3,032.2$ & 731.9 & 372.3 & 511.5 \\
\hline Abundance of cyst Heterotrophyic & 316.56 & 199.18 & 436.65 & 234.93 & 427.98 & 229.03 & 431.33 & 141.01 & 43.43 & 31.04 & 146.18 & 102.22 & 138.47 & 379.03 & 379.53 & 124.09 & 90.26 \\
\hline Abundance of cyst Undificated & 516 & 80 & 369 & 147 & 122 & 33 & 316 & 94 & 29 & 62 & 219 & 358 & 138 & 347 & 380 & 223 & 60 \\
\hline Percentege abundance of Autotrophic & 33.33 & 44.00 & 47.83 & 64.86 & 48.57 & 68.00 & 44.68 & 40.00 & 54.55 & 40.00 & 73.68 & 70.00 & 85.71 & 80.67 & 49.09 & 51.72 & 77.27 \\
\hline Percentege abundance of Heterotrophic & 25.33 & 40.00 & 28.26 & 21.62 & 40.00 & 28.00 & 31.91 & 36.00 & 27.27 & 20.00 & 10.53 & 6.67 & 7.14 & 10.08 & 25.45 & 17.24 & 13.64 \\
\hline Percentege abundance of Undificared & 41.33 & 16.00 & 23.91 & 13.51 & 11.43 & 4.00 & 23.40 & 24.00 & 18.18 & 40.00 & 15.79 & 23.33 & 7.14 & 9.24 & 25.45 & 31.03 & 9.09 \\
\hline
\end{tabular}

